\title{
Controls of metamorphic grade in shear belts
}

\author{
John Grocott
}

\begin{abstract}
The relationship between metamorphic grade and deformation is examined for shear belts occurring in Precambrian shields. A particular case, where isotherms have fallen continuously relative to an originally horizontal datum surface, for some time prior to the initiation of the shear belt and throughout its life, is examined in detail. Such behaviour of isotherms appears to be common.

A type of syn-tectonic metamorphic boundary occurring within shear belts and not coinciding with a strain gradient is discussed in detail. Such boundaries are called active facies boundaries, as mineral assemblages on each side tend to maintain perfect equilibrium with metamorphic conditions during deformation.

The orientation of active facies boundaries depends on the vertical displacement rate. In ductile thrust zones horizontal gradients in metamorphic conditions can be set up, and following erosion once active facies boundaries may be exposed. The metamorphic history of rocks in such zones will vary vertically, and, under certain circumstances, laterally. A model is set up to predict these variations, and is applied to the northern boundary of the Ikertôq shear belt, western Greenland.
\end{abstract}

\section{Introduction}

The Precambrian shield areas of many continents are cut by large scale zones of high ductile deformation initiated during the late Archaean or the early Proterozoic. These shear belts seem to herald an important change in the style of crustal deformation. Though many structural studies of shear belts have been made, metamorphic processes occurring in them are less well understood. Important in this respect is the work of Beach $(1973,1974,1976)$ and Beach \& Tarney (1978) in NW Scotland who described mineralogical and chemical changes in gneisses retrogressed from granulite facies to amphibolite facies in shear zones. In order to demonstrate the generality of his conclusions Beach (1976) also recorded changes between granulite facies rocks and their reworked equivalents in amphibolite facies from the southern boundary region of the Ikertôq shear belt in West Greenland; and similar results were obtained. In both areas variation in the degree of mineralogical change was found to correlate almost perfectly with changes in deformation intensity. The relationship between metamorphism and deformation in shear belts is not always as straightforward. A more complicated example from western Greenland is described here, and a model for its interpretation, believed to be of wider application, is set up.

Detailed structural studies in the Ikertôq shear belt revealed important differences between its northern and southern boundaries (Escher, Escher \& Watterson, 1975; Grocott, 1977a). Differences in structural and metamorphic history also occur along each margin of 
the shear belt. At the coast, the southern boundary of the shear belt is vertical, and deformation and facies boundaries are coincident. Analysis of shape fabrics in this part of the shear belt suggests that displacement is dominated by subhorizontal movements (Bak et al., 1975). In contrast the boundary between granulite and amphibolite facies rocks in coastal areas of the northern part of the shear belt occurs within the zone of intense deformation. Furthermore this facies boundary occurs in a zone characterised by overthrusting movements (Watterson, 1974; Grocott, 1977a).

As a prelude to geochemical studies in the northern boundary region of the Ikertôq shear belt, the relationship between deformation and metamorphism must be known. This contribution seeks to define this relationship. It is believed that the conclusions may apply in general to ductile shear belts in which significant vertical displacement has occurred. To emphasize the possible generality of the ideas, the likely controls of metamorphism in shear belts are firstly considered in abstract, and then applied to the northern boundary region of the Ikertôq shear belt.

\section{Types of metamorphic boundaries in shear belts}

Generally speaking, prograde metamorphic reactions can occur in the absence of appreciable deformation, but thorough retrogression is frequently 'catalysed' by deformation. Many shield areas preserve evidence of a granulite facies metamorphism in the late Archaean, and often, where granulite facies rocks are reworked along shear belts, this deformation is accompanied by retrogression. In the first instance this retrogression is frequently to amphibolite facies. Once established, deformation often continues in these zones, each successive phase commonly being associated with a lower grade, (Grocott, 1977b). This implies that the Precambrian rocks exposed in many shield areas have slowly risen in the crust throughout geological time. A corollary of this is that isotherms have fallen continuously relative to originally horizontal datum surfaces since the peak of granulite facies metamorphism. This in turn limits the nature of metamorphic boundaries which will be associated with shear belts in such terrains.

The peak of granulite facies metamorphism in the North Atlantic craton was reached $2850 \pm 100 \mathrm{Ma}$ ago (Black et al., 1973). At this time the boundary between stable amphibolite facies and stable granulite facies rocks lay above the level of the present day erosion surface over large areas. This situation is shown in figure 1a.

Shear belts began to form in the North Atlantic craton about $2700 \mathrm{Ma}$ ago. In many cases they are associated with retrogression to amphibolite facies. An explanation of this is given in figures $1 \mathrm{~b}$ and $1 \mathrm{c}$. During the time between the zenith of granulite facies metamorphism and shear belt initiation, the boundary between stable granulite facies and stable amphibolite facies conditions fell in the crust relative to the present erosion level. Since this was not accompanied by deformation, retrogression did not occur. Rocks on each side of the earlier metamorphic facies boundary became metastable as isotherms fell, and the boundary itself could then be called passive (fig. 1b).

A degree of equilibrium was re-established by the initiation of shear belts. Within these zones rocks recrystallised during deformation, and entered the facies appropriate to metamorphic conditions at each level in the shear belt. Consequently a new facies boundary between amphibolite and granulite facies rocks formed in the shear belts (fig. 1c). Provided 


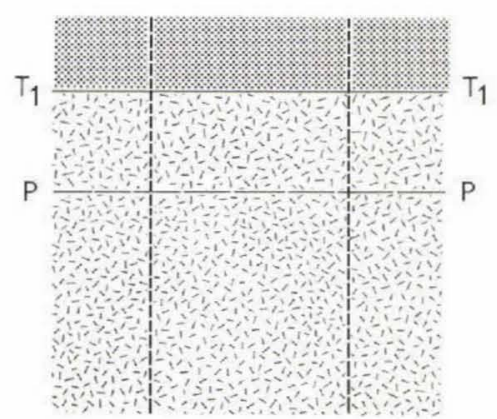

a.

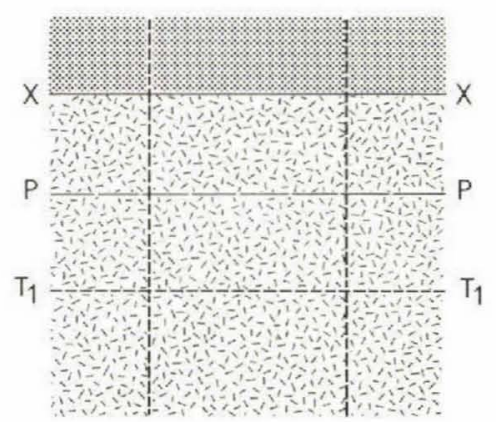

b.

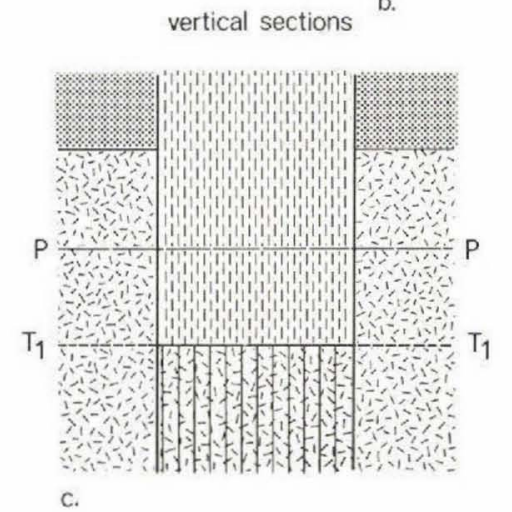

vertical sections

Fig. 1. Relationship between metamorphism and deformation in vertical shear belts with subhorizontal displacements. 1a. Facies distribution at the peak of Archaean metamorphism. $\mathrm{T}_{1}-\mathrm{T}_{1}$ : granulite-amphibolite facies boundary. P-P: present level of erosion. Random dashes: unreworked granulite facies. Stipple: amphibolite facies. 1b. X-X: facies boundary established in 1a preserved in the absence of deformation. $\mathrm{T}_{1}-\mathrm{T}_{1}$, the theoretical boundary between stable granulite and stable amphibolite facies rocks has fallen with temperature relative to $\mathrm{P}-\mathrm{P}$. All rocks in the section are metastable. 1c. Effect of reworking. Active facies boundary is established at $T_{1}-T_{1}$ between stable amphibolite facies rocks (oriented dashes) and stable granulite facies rocks (random dashes with superimposed lines) in the shear belt. Vertical dynamic retrograde boundaries define the shear belt. All rocks outside the shear belt are metastable.

it remains at one level long enough for complete equilibrium to be reached, rocks on each side of this facies boundary are stable. There is no strain gradient across metamorphic boundaries of this type, which, when facies change is involved, are called active facies boundaries. Where isotherms have continuously fallen in the crust relative to an originally horizontal datum surface, rocks on both sides of such a boundary will have retrogressed although they may not change facies at all levels.

Each shear belt occurs between metamorphic boundaries separating stable mineral assemblages within the zone from metastable assemblages outside (fig. 1c). Provided isotherms have always fallen with respect to an originally horizontal datum surface, these boundaries will be retrogressive at all levels, although a facies change across them need not 
occur (fig. 1c). Such boundaries are called dynamic retrograde boundaries to emphasize the coincidence of a deformation boundary with a fall in metamorphic grade.

Summarising, during ductile deformation shear belts in the North Atlantic craton contained active facies boundaries, and were defined by dynamic retrograde boundaries. Facies boundaries which can be studied today are of course all passive. In shear belts with large vertical displacements it may be possible to distinguish originally active facies boundaries from the more usually exposed dynamic retrograde boundaries.

\section{Controls of metamorphic grade in shear belts with subhorizontal displacements}

In any shear belt the conditions affecting metamorphic grade will be temperature, confining pressure, strain intensity and the concentration of mobile components. It has been shown that metasomatism is an important process in shear belts and the presence of a metasomatic fluid has been inferred (Beach, 1976). Where this fluid exist in rocks and how it passes through them to effect metasomatism is unknown (Vernon, 1976 p. 53). Assuming that such a fluid exists, its composition will depend on the composition of the rocks from which it was derived, and the unknown processes involved. Thereafter the composition of this fluid will change as it passes through the shear belt reacting as it does so with the solid phases, tending to reach equilibrium at different levels according to the temperature and pressure. Beach (1976) has shown that the degree of equilibrium in shear belts in NW Scotland correlates positively with deformation intensity.

In a vertical shear belt characterised by subhorizontal movements it seems reasonable to assume that, provided strain is homogeneous, active facies boundaries dependent on the above variables will be horizontal within the zone. Provided conditions in the shear belt are stable, all metamorphic reactions will reach equilibrium. A series of active facies boundaries could be identified within such a shear belt based on mineral assemblages at different levels but textural evidence, in the form of reaction rims or pseudomorphs, for the reactions on which facies boundaries could be based would be absent.

In contrast the vertical dynamic retrograde boundaries of this shear belt should exhibit textural evidence of the reactions involved in retrogression. This is because many shear belts preserve a strain gradient across their retrogressive boundaries. Where the deformation is low, retrogression will be partial and textural evidence of this, such as reaction rims and pseudomoprhs, common. In contrast to dynamic retrograde boundaries, no strain gradient will exist across active facies boundaries.

\section{Controls of metamorphic grade in zones of ductile overthrusting}

Displacements in many shear belts in the North Atlantic craton are dominated by subhorizontal movements within vertical shear planes (Bak et al., 1975). The Ikertôq shear belt also has important components of vertical displacements in ductile thrust zones (Escher et al., 1975; Grocott, 1977a). Where displacements are horizontal, there is little chance that a once active facies boundary within a shear belt will eventually be exposed, unless it is tilted during uplift. On the other hand displacements with large vertical components increase the possibility that a once active facies boundary will be exposed.

The reasoning behind this depends on the assumption that in such shear zones isotherms 


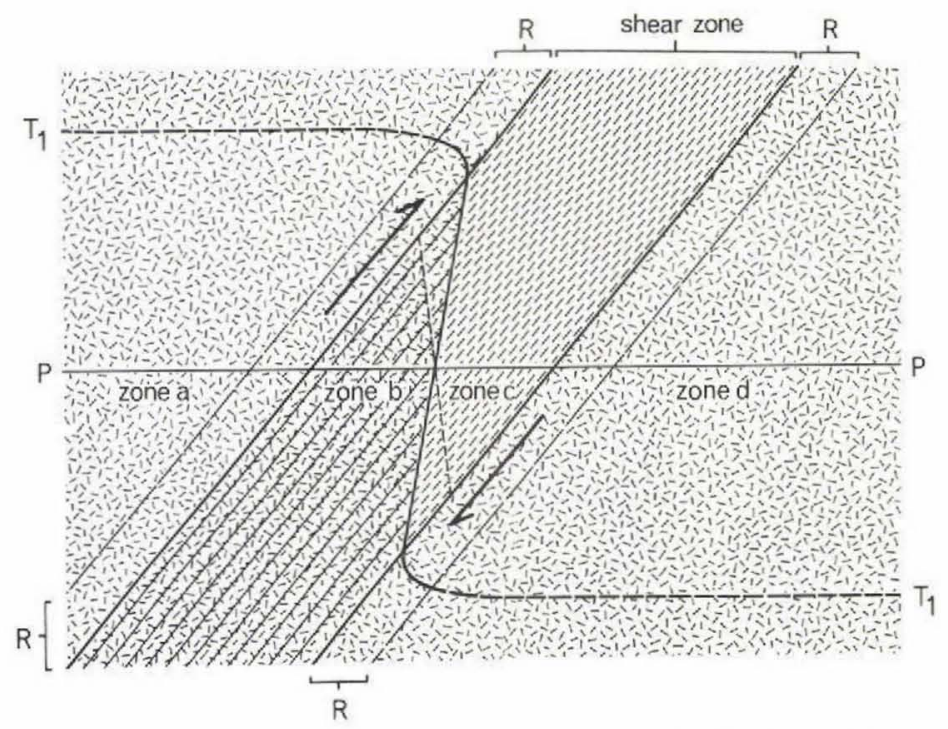

Fig. 2. Position of active facies boundaries in ductile thrust zones. $T_{1}-T_{1}$ : theoretical boundary between stable amphibolite-stable granulite facies rocks outside thrust zone, and active facies boundary in the thrust zone. P-P: present erosion level. R: zone of partially retrogressed rocks at shear zone margin. Zones a-d see text. Ornament as in figure 1. Dashed line in the shear zone is a modified position for the facies boundary, see text. All rocks outside the shear belt are metastable.

are displaced from the horizontal faster than they can recover this position by thermal relaxation. Figure 2 shows the effect of an overthrusting shear belt on a notional boundary between stable and metastable granulite facies rocks. In the diagram the boundary is deformed as if it were a material line. This will only be true if this is a line of constant metamorphic conditions, in this case:

(a) no thermal relaxation occurs;

(b) no erosion of the upthrust rocks occurs at the earth's surface, so that the confining pressure does not vary across the shear belt;

(c) composition of the fluid phase and its mobile components in the shear belt are neglected.

Erosion of the upthrust unit will occur, so it is likely that confining pressure will decrease towards the upthrown unit across the shear zone. Assuming some thermal relaxation even at maximum strain rates, the position of the active boundary will be modified from the 'material line' model as shown on figure 2. An adjustment to the position of the active facies boundary in the shear belt which takes the composition of the fluid phase and its mobile components into account can only be made if specific information is available. In any case the position of the boundary between stable and unstable granulite facies rocks prior to formation of the shear belt is notional. However this approach serves to illustrate the form that active facies boundaries would take in a shear belt characterised by ductile 
overthrusting and emphasises that a horizontal temperature gradient would be produced. Furthermore the 'material line' model is relevant to the example described later from the Ikertôq shear belt. If the section illustrated in figure 2 were uplifted and eroded to the surface P-P, four metamorphic/structural zones would be revealed (zones a-d on fig. 2 ).

\section{Zone a}

Granulite facies gneisses which predate the shear belt. Close to the shear belt these are partially recrystallised towards mineral assemblages stable at the highest grade of metamorphism found in the shear belt. Provided isotherms have fallen with respect to an originally horizontal datum the boundary with the shear belt will be a dynamic retrograde boundary, though facies change need not occur at all levels. Reaction rims around minerals are common.

\section{Zone b}

Granulite facies rocks thoroughly recrystallised and strongly deformed in the shear belt. Grade decreasing towards the facies boundary between zones b and c, but all textures show evidence of equilibrium. There is no strain gradient across the facies boundary between $b$ and $\mathrm{c}$.

\section{Zone c}

Amphibolite facies rocks thoroughly recrystallised and strongly deformed in the shear belt. Grade decreasing towards the retrogressive facies boundary between $c$ and $d$, but all textures show evidence of equilibrium.

\section{Zone d}

Granulite facies gneisses which predate the shear belt. Close to the shear belt they are partially recrystallised towards mineral assemblages stable at the lowest grade in the shear belt. This is a dynamic retrograde boundary between granulite and amphibolite facies, and, like that between zones $\mathbf{a}$ and $\mathbf{b}$, it coincides with a strain gradient.

A final point is that provided isotherms fell in the crust prior to the initiation of the overthrusting zone, relative to an originally horizontal datum, all the reworked rocks along the line at the present erosion section (and at any other level) will have retrogressed during reworking, though they will not necessarily have changed facies. Thus rocks on both sides of the active facies boundary will have retrogressed during reworking. Rocks will only prograde if the isotherms they contain rise in the crust faster than any vertical displacements.

\section{Effect of thermal relaxation}

The rate at which strain rate decreases at the end of a deformation phase in shear belts is unknown. It is probable that thermal relaxation will increase in response to a slow decrease in strain rate, and the position of the active facies boundary in the shear belt will adjust accordingly (fig. 3a). This tendency to smooth out isotherms in response to falling strain rate may also produce a zone of prograded rocks outside the shear belt on the downthrow side (fig. 3a). It is less likely, in the absence of deformation, that a corresponding zone of retrogressed rocks will form outside the shear belt on the upthrow side (fig. 3a). If strain in the shear belt abruptly ceases, the displaced isotherm will decay as shown in figure $3 \mathrm{~b}$. In this 




a.

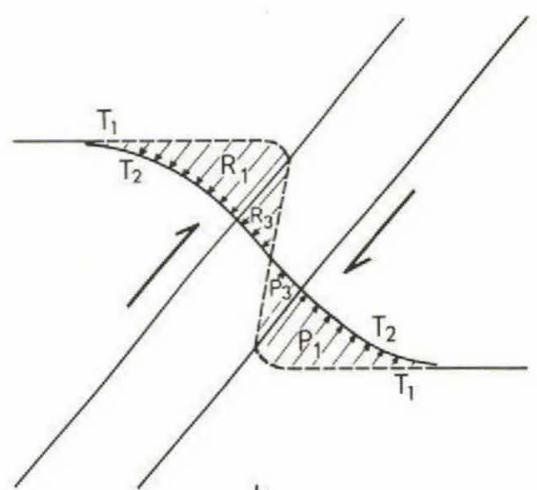

b.

Fig. 3. Effect of thermal relaxation on facies distribution. 3a. Slow decrease in strain rate. Isotherm $T_{1}-T_{1}$ relaxes to $T_{2}-T_{2}$. Rocks in segment $R_{2}$ retrogress to reach a new equilibrium, rocks in $P_{2}$ prograde. Outside the shear belt rocks in $R_{1}$ do not retrogress in the absence of deformation, rocks in $P_{1}$ prograde but it is unlikely, in the absence of deformation, that perfect equilibrium will be reached everywhere. 3b. Strain rate abruptly ceases. $T_{1}-T_{1}$ relaxes to $T_{2}-T_{2}$. Prograde reactions tend to occur in segments $P_{1}$ and $\mathrm{P}_{3}$, but in the absence of deformation will not be complete everywhere. Retrogression is unlikely in segments $R_{1}$ and $R_{3}$ without deformation.

case the active facies boundary will not migrate, but a zone of prograde metamorphism may develop on the downthrow side of the shear belt (fig. 3b). Whether or not these prograde zones are seen will depend on the position of the present day erosion surface relative to the active facies boundary when strain ceased (fig. 3). If such zones do occur in a shear belt, prograde reaction textures which cannot be related to a strain gradient may be present.

\section{An example: the northern margin of the Ikertôq shear belt}

The Ikertôq shear belt occurs in the Nagssugtoqidian of W. Greenland as defined by Ramberg (1948). Two phases of intense ductile deformation are recognised, separated by the intrusion of a basic dyke swarm; the Kangâmiut dykes. All three events are believed to be part of a continuous process occurring under high grade metamorphic conditions (Bridgwater et al., 1973; Escher et al., 1976). Detailed field work in the shear belt has shown that the geometry of structures and tectonite fabrics formed is consistent with a deformation model characterised by simple shear strain (Escher et al., 1975; Bridgwater et al., 1973; Escher \& Watterson, 1974; Grocott, 1979).

The shear belt has an irregular shape (fig. 4), and this can be shown to be a consequence of overlap between the two phases of ductile strain. The earlier of these, Nag. 1, is represented by horizontal movements within a vertical, E-W trending shear plane, whilst later post-dyke deformation, Nag. 2, is dominated by overthrusting displacements towards the SSE. As a result of these interrelationships each boundary of the shear belt has a different structural and metamorphic history, which also varies along their length.

Throughout this account the granulite-amphibolite facies boundary is defined simply by the appearance of hypersthene in granodioritic gneisses which constitute the dominant 
lithology. This is convenient for two reasons. Firstly, hypersthene bearing granodioritic gneisses weather a distinctive brown colour, allowing their distribution to be quickly and accurately mapped, and secondly hypersthene appears in a wide range of compositions at approximately the same grade in this area, so that the boundary between hypersthene free and hypersthene bearing rocks is quite sharp. Consequently for the purposes of this paper, this criterion provides a useful definition of this facies boundary.

At the coast Nag. 1 deformation can be recognised across much of the width of the shear belt, except in a large granulite facies lacuna centred on Kíngaq (fig. 4). Immediately north of this augen structure superimposed Nag. 2 strain is weak, but increases steadily northwards culminating in a $7 \mathrm{~km}$ wide zone of intense overthrusting at the northern boundary. Only Nag. 1 deformation is recognised south of Kingaq, and here the boundary of the shear belt is a dynamic retrograde facies boundary coincident with a steep strain gradient.

At the northern boundary of the shear belt facies and deformation boundaries are parallel, but do not coincide. The facies boundary between granulite facies rocks to the north and amphibolite facies rocks occurs within the zone of intense Nag. 2 strain, and does not coincide with a strain gradient (fig. 4). The deformation boundary in this part of the shear belt lies $5 \mathrm{~km}$ further north. Five structural and metamorphic areas have been recognised across this boundary at the coast, and these are described below (fig. 5). It is emphasised that they may not be typical of the boundary as a whole, and relationships further east are described in a contribution by Korstgård (this volume).

\section{Structural and metamorphic subdivisions}

Much structural detail, especially that concerning shape fabrics, has been recorded elsewhere (Grocott, 1979), and only the important characteristics of each area essential to later arguments are repeated here.

\section{Area A}

Both gneisses and Kangâmiut dykes contain upper amphibolite facies mineral assemblages, though at some localities epidote grains occur in granodioritic gneisses. Subhorizontal E-W stretching fabrics associated with a strong foliation which predates intrusion of Kangâmiut dykes argues for a strong component of Nag. 1 deformation. This fabric and the dykes are folded, and this, together with the deformation path defined by shape fabrics indicates a weak to moderate component of Nag. 2 strain.

\section{Area B}

Also in amphibolite facies; Nag. 2 strain increases steadily from area A and across area B. This increase is marked by the development of a strong foliation dipping about $55^{\circ} \mathrm{NNW}$, together with a change in orientation of the stretching lineation until it has a down dip plunge on foliation planes. Kangâmiut dykes become strongly deformed and lose any discordance, while earlier fold closures become isoclinal as their fold axes track the steepening plunge of the stretching fabric. 


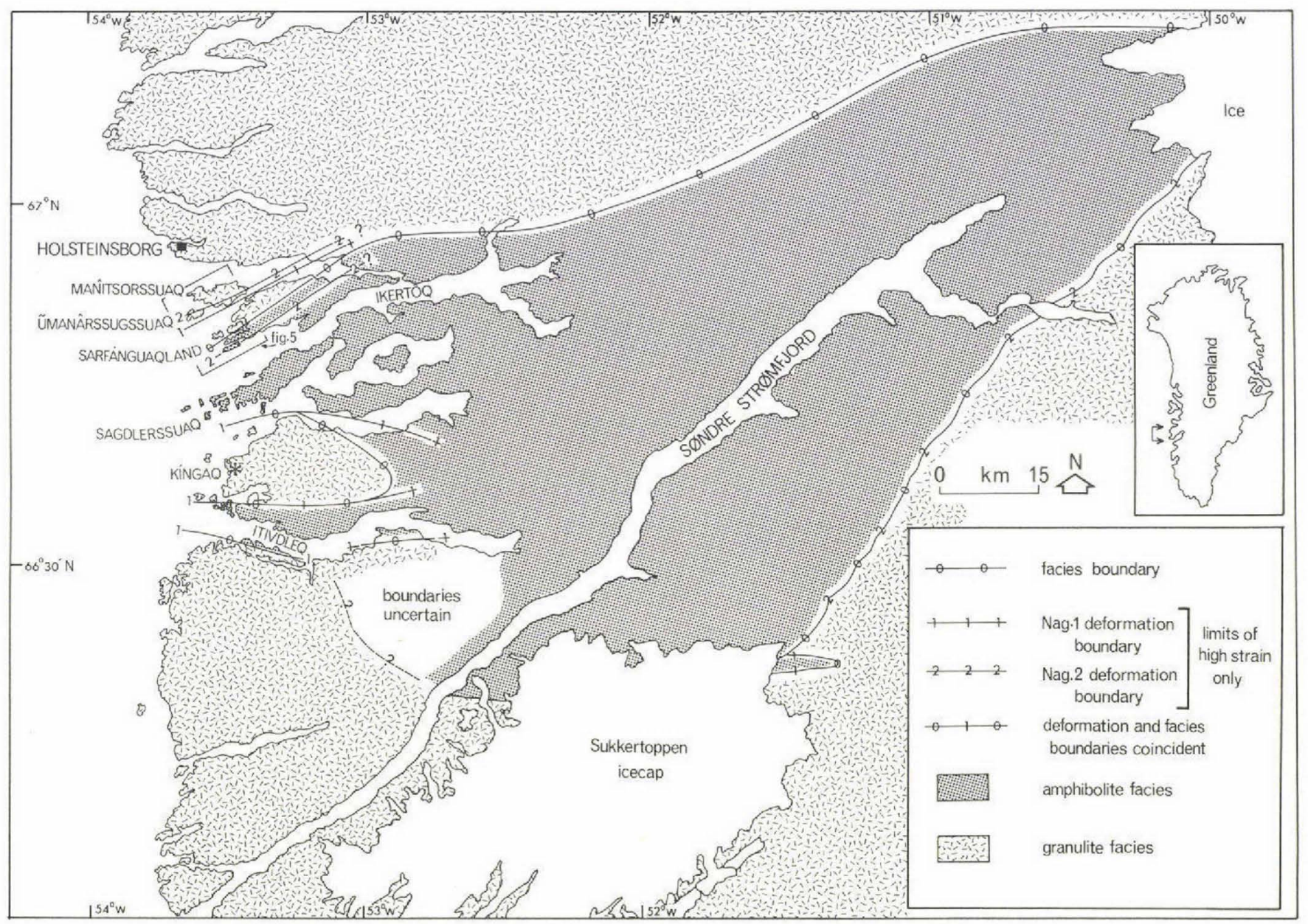

Fig. 4. Facies and deformation boundaries, so far as are known, in the Ikertôq shear belt. 


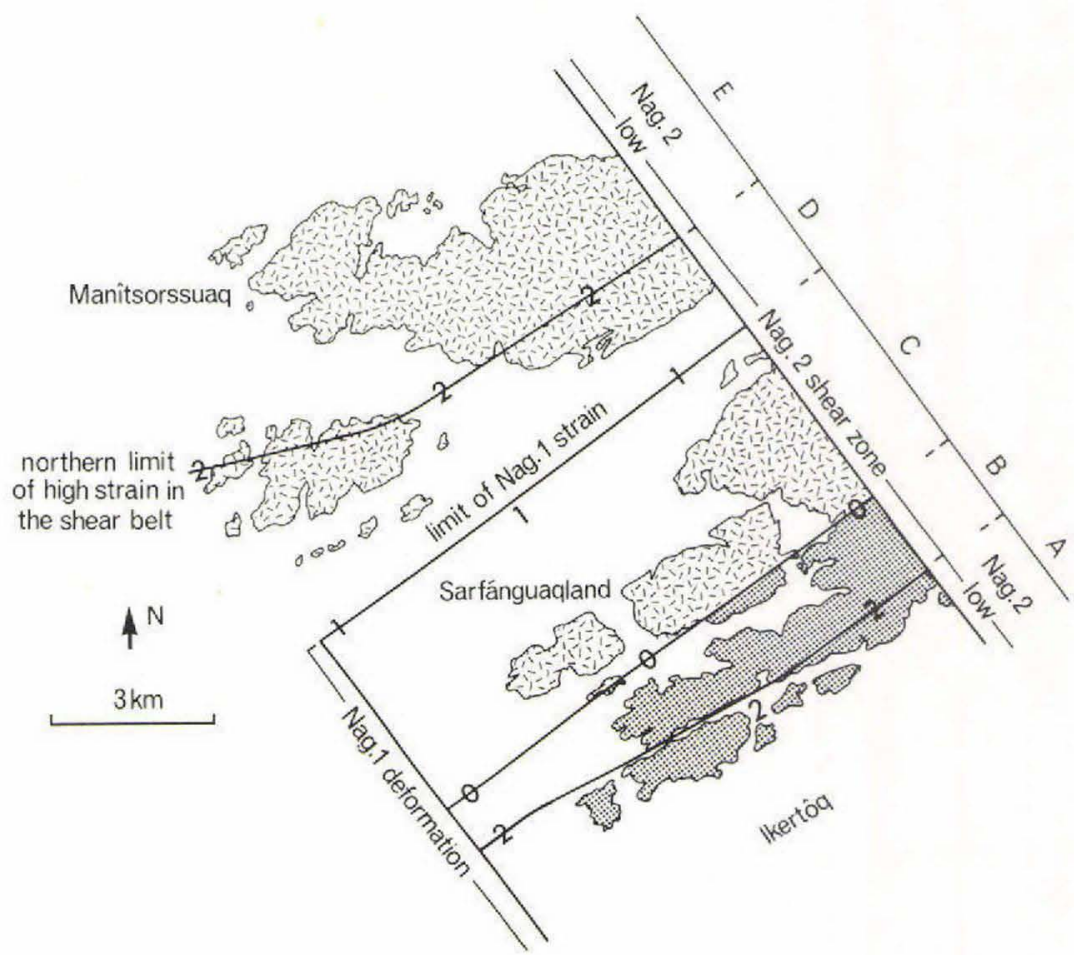

Fig. 5. Metamorphic and structural boundaries in the N.W. part of the Ikertôq shear belt. Random dashes, granulite facies; stipple, amphibolite facies. Zones A-E, see text.

\section{Area C}

Both gneisses and Kangâmiut dykes in area $\mathrm{C}$ are in granulite facies, and this is an area of intense Nag. 2 strain. Deformation intensity increases slightly north of the facies boundary, and the dykes become concordant basic schlieren, but a significant strain gradient across the facies boundary does not occur. Where Nag. 2 deformation is low in areas B and C, fabric orientation and dyke-gneiss relationships typical of Nag. 1 deformation are preserved.

\section{Area D}

Contrasts drawn between this granulite facies area and area $\mathrm{C}$ enable the northern limit of Nag. 1 strain to be recognised (fig. 5). In area D discordant basic dykes with granulite facies parageneses are probably Kangâmiut dykes much less deformed than immediately further south. This indicates that Nag. 2 strain is lower. In apparent conflict with this observation is the fact that the transverse stretching fabric is more constant than anywhere else in the boundary region. On its own this suggests that Nag. 2 deformation is at a maximum. In fact constant orientation of shape fabrics is interpreted to mean that predyke strain (Nag. 1) is weak, rather than postdyke strain particularly strong, as the dykes are not strongly deformed. Consequently the northern limit of intense Nag. 1 deformation is drawn between areas $\mathrm{C}$ and $\mathrm{D}$ (fig. 5). 


\section{Area $\mathrm{E}$}

Areas $\mathrm{B}, \mathrm{C}$ and $\mathrm{D}$ constitute the overthrusting shear zone in this part of the shear belt, and Nag. 2 strain decreases gradually north and south on each side. Area $E$ is granulite facies and is characterised by great variation in the orientation of shape fabrics around large scale open dome and basin-like folds of Nag. 2 age. These folds have a flat-lying envelope, so that prior to their formation fabrics were flat lying and therefore unaffected by Nag. 1 deformation. Across the boundary between areas $\mathrm{D}$ and $\mathrm{E}$ these folds tighten abruptly, and fabric orientation becomes uniform. This boundary is taken to be the shear belt deformation boundary.

Dome and basin-like folds in area $E$ have an axial planar Nag. 2 mineral fabric. Northwards these folds decrease in tightness and amplitude and the mineral fabric dies out as the granulite facies gneisses become almost flat lying. There are also areas nearer the deformation boundary which contain no evidence of Nagssugtoqidian deformation, and are presumably in their Archaean structural and metamorphic state.

\section{Timing of granulite facies metamorphism}

Two lines of evidence show that recrystallisation under granulite facies conditions occurred at the present level of erosion in the zone of intense Nag. 2 strain in the northern part of the shear belt. The first concerns shape fabrics formed during Nag. 2 deformation. Mafic mineral aggregates defining these fabrics include fresh hypersthene so that it is clear that in these aggregates hypersthene was recrystallising during this deformation. The second line of evidence is based on mineralogy of Kangâmiut dykes. North of the facies boundary in areas C, D and E these dykes contain metamorphic hypersthene. Aggregates of minerals in the dykes include hypersthene, and define shape fabrics consistent in orientation with Nag. 2 deformation. Therefore the last granulite facies metamorphism in this part of the shear belt is synchronous with this deformation, and post-dates intrusion of the dykes.

Kangâmiut dykes only occur as far north as the southern part of area $E$, and this seems to be the northern limit of the swarm at the coast. Although Nagssugtoqidian deformation is relatively weak in area $\mathrm{E}$, the gneisses have recrystallised in granulite facies during Nag. 2, and the dykes contain metamorphic hypersthene. Further north Nagssugtoqidian deformation decreases, and in some areas is absent. These areas have granulite facies parageneses and presumably are in pre-Nagssugtoqidian structural and metamorphic state. A boundary between Nagssugtoqidian and Archaean granulite facies rocks north of the shear belt deformation boundary has not yet been drawn.

Pre-Nagssugtoqidian granulite facies rocks are therefore recognised on each side of the shear belt, and also within it as the Kíngaq and smaller augen. This indicates that such rocks occupied the whole of the present area of the shear belt prior to its initiation.

\section{Explanation of metamorphic grade in the coastal part of the Ikertô $q$ shear belt}

Principles outlined earlier can be used to explain the relationship between deformation and metamorphism in the shear belt. At the present level of erosion in the Itivdleq district, granulite facies gneisses retrogress to amphibolite facies across the vertical Nag. 1 deformation boundary. This retrogression implies that after granulite facies metamorphism in the 
Archaean, the theoretical boundary between stable granulite facies and stable amphibolite facies fell below the present erosion level (fig. 1b). As deformation began in the shear belt dynamic retrograde boundaries formed at each margin (fig. 1c). Since displacements are horizontal, active facies boundaries formed in the shear belt will also be horizontal. A boundary between amphibolite and granulite facies rocks is predicted to occur some distance below the present erosion surface in this part of the shear belt (fig. 1c). In this respect it may be relevant that Kangâmiut dykes occasionally carry large xenoliths of foliated granulite facies gneiss.

Nag. 1 deformation can be recognised across much of the present day width of the shear belt (fig. 4). After this phase of movement it is likely that the shear belt consisted of an E-W trending, vertical $40 \mathrm{~km}$ wide zone defined at the present erosion level by coincident deformation and retrogressive facies boundaries. The shear belt contained horizontal active facies boundaries, and the present erosion level cut through the amphibolite facies segment defined by these boundaries.

Kangâmiut dykes intruded at the close of Nag. 1 deformation. Where Nag. 2 strain is absent dykes often retain primary intrusive features. Some dykes contain igneous textures, but in many cases, despite lack of evidence of later deformation in the country rocks, dykes have tectonite fabrics. Such fabrics are orientated similarly to those associated with Nag. 1 deformation, and are believed to have formed as the dyke cooled from igneous temperatures after crystallisation, and are called syn-consolidation fabrics (Nash, this volume). Since these fabrics have a Nag. 1 orientation the newly intruded and very ductile dykes are thought to have absorbed a late increment of Nag. 1 strain. The mineral assemblages making up these shape fabrics belong to the upper amphibolite facies, giving the metamorphic grade at the close of Nag. 1 at the level of the present erosion surface. At lower levels, below the active boundary in granulite facies country rocks, syn-consolidation fabrics formed in the dykes will be defined by a granulite facies mineral assemblage.

The zone of Nag. 2 deformation in the northern part of the shear belt has a large vertical component of displacement, and for reasons discussed earlier, it is probable that it contains an active facies boundary with a form similar to that shown on figure 2 .

At the southern side of the Nag. 2 shear zone north of Ikertôq (fig. 5), the first increments of this deformation recrystallise gneisses and dykes, but the mineral assemblages remain those of the upper amphibolite facies. Therefore at the present level of erosion in the shear belt, isotherms did not change level between the period of dyke intrusion and onset of Nag. 2 deformation. In this case the active facies boundary formed in the shear belt by Nag. 1 deformation will pass into the active facies boundary in the Nag. 2 shear zone in the way shown on figure 6 . This line, $T_{1}-T_{1}$ in figure 6 , passes through the Nag. 2 shear zone as would a deformed material line. It will only show the position of the facies boundary accurately if the controls of metamorphism remain identical to those existing during Nag. 1 deformation. Relatively minor modifications to its position may occur according to arguments made earlier concerning pressure and temperature (fig. 2), but no account is taken of the composition of any metasomatic fluid in this zone. Taking such a factor into account may affect the position of the active facies boundary in the Nag. 2 shear zone, but not its general form.

If isotherms did fall between the period of dyke intrusion and the onset of Nag. 2 deformation, figure 6 should be modified to show a zone of gneisses which had retrogressed from 




Fig. 6. Relationship between metamorphic grade and deformation at the northern boundary of the Ikertôq shear belt. $\mathrm{T}_{1}-\mathrm{T}_{1}$ : active facies boundary. P-P: present erosion level; $\mathrm{N}_{1}$ : northern boundary of Nag. 1 deformation. $\mathrm{N}_{2}$ : Nag. 2 shear zone. Segments 1,2 and 3, see text. Ornament as in fig. 1. Provided isotherms were not lowered between dyke intrusion and onset of Nag. 2 strain, only unreworked granulite facies rocks are metastable. Zones $\mathrm{A}$ to $\mathrm{E}$ along line $\mathrm{P}-\mathrm{P}$ are comparable with zones $\mathrm{A}$ to $\mathrm{E}$ in fig. 5 .

granulite to amphibolite facies within the Nag. 2 shear zone above the line $T_{1}-T_{1}$. In addition $T_{1}-T_{1}$ would no longer coincide with the granulite-amphibolite faciss boundary outside the Nag. 2 shear zone, and a zone of metastable granulite facies rocks would exist above it.

There is some evidence for such a fall in isotherms at this time. Such a form presumably reflects a pause between dyke intrusion and initiation of Nag. 2 strain. This evidence occurs south of Ikertôq on the island of Sagdlerssuaq. Here homogeneous components of Nag. 2 strain are very weak (Grocott, 1979). Nevertheless epidote is common in the gneisses suggesting that the first increments of Nag. 2 recrystallisation occurred at lower rather than upper amphibolite facies conditions at the present erosion level.

The zone of intense overthrusting deformation at the northern boundary of the shear belt contains the boundary of the shear belt established during Nag. 1. The position of this boundary, deformed as a material line is shown in figure 6 . This figure shows the Nag. 2 shear zone defined by two dynamic retrograde boundaries at its margins, and divided by an active facies boundary and the displaced Nag. 1 shear zone boundary. Each volume of rocks 
limited by these boundaries (1-3 on figure 6) has its own structural and metamorphic history. In segment 1 gneisses were reworked during Nag. 1 deformation and retrogressed to amphibolite facies. Some dykes developed syn-consolidation fabrics with an amphibolite facies mineralogy at this stage. During Nag. 2 deformation gneisses and dykes in segment 1 recrystallised in amphibolite facies. In segment 2 gneisses were reworked during Nag. 1 strain, but lay below the active granulite-amphibolite facies boundary in the shear belt at that time, and therefore recrystallised in granulite facies. Syn-consolidation fabrics formed in Kangâmiut dykes in this segment will also have a granulite facies mineralogy. During Nag. 2 deformation, these rocks were displaced upwards during reworking. Assuming the active granulite-amphibolite facies boundary established during Nag. 1 deformation is deformed into the Nag. 2 shear zone as a line of constant metamorphic conditions (a material line), gneisses and dykes will recrystallise in granulite facies during Nag. 2 deformation. In this case the metamorphic grade of gneisses on each side of the active facies boundary will not change during Nag. 2 deformation. If this is not the case, and this line is not one of constant metamorphic conditions, it will not accurately predict the position of the granulite-amphibolite facies boundary. A new active facies boundary will then form in the Nag. 2 shear zone and some rocks in the vicinity of the old active facies boundary will reach equilibrium by prograde or retrograde reactions as appropriate (e.g. fig. 2). Because of the nature of active facies boundaries, once equilibrium is reached no textural evidence of this adjustment will be preserved. Segment 3 lay north of the shear belt boundary formed during Nag. 1 deformation, and consequently remained in granulite facies after this deformation. During Nag. 2 deformation these rocks lay below the active granulite-amphibolite facies boundary, and therefore recrystallised in granulite facies.

A line which corresponds to the present day erosion level is shown in figure 6. At this level, a plan view across the Nag. 2 shear zone would contain five zones A-E in figure 6 . These five zones, and the nature of the boundaries between them have precisely the same characteristics as those which occur on the ground and described earlier under structural and metamorphic subdivisions (Fig. 5). Northwards across zones A and B Nag. 2 strain increases as gneisses and dykes recrystallise in upper amphibolite facies, the gneisses having originally retrogressed from granulite facies during Nag. 1 deformation at this level. Between zones B and $C$ the preserved active facies boundary is crossed, and gneisses and dykes below the facies boundary during Nag. 1 deformation recrystallised in granulite facies during Nag. 2 . Zones $\mathrm{C}$ and $\mathrm{D}$ are separated by the deformed original northern boundary of the shear belt. During Nag. 2 both areas recrystallised in granulite facies, but in area D Nag. 1 deformation and recrystallisation is absent. In area $\mathrm{C}$ granulite facies gneisses are noticeably more banded than in area $D$, probably reflecting the additional deformation they have suffered, recrystallisation decreases northwards across area $E$, concomitant with decrease in the amount of Nag. 2 strain in these granulite facies rocks.

As strain rate decreased in the Nag. 2 shear zone towards the end of this phase of deformation, thermal relaxation is likely to have occurred (fig. 3). If strain rate decreased gradually allowing the active facies boundary to adjust its position, evidence of thermal relaxion might only occur to the south of the Nag. 2 shear zone. Here isotherms would temporarily rise (fig. 3a), and a static prograde metamorphism might occur. Evidence for this might be preserved as reaction rims. If strain ceased abruptly relaxation of the isotherms in the same way could produce a static prograde metamorphism in the southern part of the 
shear zone as well as further south (fig. $3 \mathrm{~b}$ ). Whether or not such zones of prograde metamorphism were exposed would depend critically on the level of the present erosion section in the shear belt (fig. 3).

A number of mineralogical variations occur as the active facies boundary in the Nag. 2 shear zone is approached (Grocott, 1977a). These include decrease in An content of plagioclase from $\mathrm{An}_{38-40}$ in granulite facies rocks to $\mathrm{An}_{20-24}$ in amphibolite facies rocks, and decreases in modal clinopyroxene and hypersthene coupled with increase in biotite as the boundary is approached. These changes occur gradually and no related reaction textures have been observed. At this level in the shear belt therefore there is no evidence for partial adjustment of the position of the active facies boundary in response to thermal relaxation. Changes in the metamorphic grade of Kangâmiut dykes closely follows that of the gneisses across the area studied and elsewhere (Korstgård, this volume).

\section{Conclusions}

It is concluded that two distinct types of metamorphic boundary occur in large scale shear belts. The first is the familiar retrogressive boundary which coincides with a steep strain gradient at the margin of shear belts. The second is less often recognised and occurs as metamorphic conditions vary with depth. It produces metamorphic boundaries called, where facies change is involved, active facies boundaries across which mineral assemblages are likely to be in perfect equilibrium. It will not coincide with a deformation boundary.

Active facies boundaries are most likely to be exposed in zones of ductile overthrusting when thermal relaxation does not keep pace with strain rate. They may also be exposed in shear belts with subhorizontal displacements if these are subsequently tilted. In zones of ductile overthrusting in which the active facies boundary is not horizontal, the facies distribution depends critically on the present day erosion level.

The boundary between granulite and amphibolite facies rocks within the Nag. 2 shear zone at the northern margin of the Ikertôq shear belt occurs because the active facies boundaries are not horizontal. Recrystallisation in granulite facies to the north and in amphibolite facies to the south is contemporaneous with overthrusting deformation. The active nature of this boundary is reflected by absence of a strain gradient across it and the complete mineralogical equilibrium within the zone.

Lack of reaction textures, particularly in the southern part of this Nag. 2 overthrusting zone suggests also that prograde reactions in response to thermal relaxation at a late stage in the movement of the shear zone did not occur. Such a lack of prograde reactions may be a consequence of the present day erosion level, rather than non-occurrence of thermal relaxation.

Acknowledgements. The work in West Greenland was undertaken as part of the Liverpool University Precambrian boundary programme, supported by N.E.R.C. grant GR3/1785 and carried out with the cooperation of the Geological Survey of Greenland during my tenure of a N.E.R.C. research studentship. I am grateful to my colleagues at Liverpool and Swansea for helpful discussion, and to Mrs. $V$. Jenkins for typing successive drafts of the manuscript. 


\section{References}

Bak, J., Grocott, J., Korstgård, J., Nash, D., Sørensen, K., \& Watterson, J. 1975: Tectonic implications of Precambrian shear belts in western Greenland. Nature 254, 566-569.

Beach, A. 1973: The Mineralogy of high temperature shear zones at Scourie, N. W. Scotland. J. Petrol. 14, 231-248.

Beach, A. 1974: Amphibolitisation of Scourian granulites. Scott. J. Geol. 10, 35-43.

Beach, A. 1976: The interrelations of fluid transport, deformation, geochemistry and heat flow in early Proterozoic shear zones in the Lewisian complex. Phil. Trans. R. Soc. Lond. A, 280, 569-604.

Beach, A., \& Tarney, J. 1978: Major and trace element patterns established during retrogressive metamorphism of granulite facies gneisses, N. W. Scotland. Precambrian Res. 7, 325-348.

Black, L. P., Moorbath, S., Pankhurst, R. J., \& Windley, B. F. 1973: ${ }^{207} \mathrm{~Pb} /{ }^{206} \mathrm{~Pb}$ whole rock age of the Archaean granulite facies metamorphic event in West Greenland. Nature 244, 50-53.

Bridgwater, D., Escher, A., Nash, D. F., \& Watterson, J. 1973: Investigations on the Nagssugtoqidian boundary between Holsteinsborg and Kangâmiut, central West Greenland. Rapp. Grønlands geol. Unders. 55, 22-25.

Bridgwater, D., Escher, A., \& Watterson, J. 1973: Tectonic displacements and thermal activity in two contrasting Proterozoic mobile belts from Greenland. Phil. Trans. Royal Soc. Lond. A, 273, 513-533.

Escher, A., Escher, J. C., \& Watterson, J. 1975: The reorientation of the Kangâmiut dyke swarm, West Greenland. Can. J. Earth Sci. 12, 158-173.

Escher, A., Jack, S., \& Watterson, J. 1976: Tectonics of the North Atlantic Proterozoic dyke swarm. Phil. Trans. R. Soc. Lond. A, 280, 529-539.

Escher, A., \& Watterson, J. 1974: Stretching fabrics, folds and crustal shortening. Tectonophysics 22, 223-231.

Grocott, J. 1977a: The northern boundary of the Ikertôq shear belt, west Greenland. Thesis, Ph.D., Univ of Liverpool (unpubl.).

Grocott, J. 1977b: The relationship between Precambrian shear belts and modern fault systems. J. geol. Soc. Lond. 133, 257-262.

Grocott, J. 1979: Shape fabrics and superimposed simple shear strain in a Precambrian shear belt, West Greenland. J. geol. Soc. Lond. 136, 471-488.

Korstgård, J. A. 1979: Metamorphism of the Kangâmiut dykes and the structural evolution of the southern Nagssugtoqidian boundary in the Itivdleq-Ikertôq region, West Greenland. Rapp. Grønlands geol. Unders. 89 (this volume).

Nash, D. 1979: An interpretation of irregular dyke forms in the Itivdleq shear zone, West Greenland. Rapp. Grønlands geol. Unders. 89 (this volume).

Ramberg, H. 1948: On the petrogenesis of the gneiss complexes between Sukkertoppen and Christianshaab, West Greenland. Meddr dansk geol. Foren. 11, 312-327.

Vernon, R. H. 1976: Metamorphic processes. London: George Allen \& Unwin, 247 pp.

Watterson, J. 1974: Investigations on the Nagssugtoqidian boundary in the Holsteinsborg district, central West Greenland. Rapp. Grønlands geol. Unders. 65, 33-36.

Department of Geology,

University College,

Swansea,

U.K.
Present address: Geologisch Instituut, Universiteit van Amsterdam, Nieuwe Prinsengracht 130 , 1018 VZ Amsterdam, 